Research Article

\title{
Northern Long-Eared Bat (Myotis septentrionalis) Day-Roost Loss in the Central Appalachian Mountains following Prescribed Burning
}

\author{
W. Mark Ford $\left(\mathbb{D},{ }^{1}\right.$ Joshua B. Johnson, ${ }^{2}$ and Melissa Thomas-Van Gundy ${ }^{3}$ \\ ${ }^{1}$ U.S. Geological Survey, Virginia Cooperative Fish and Wildlife Research Unit, Blacksburg, VA 24061, USA \\ ${ }^{2}$ Pennsylvania Game Commission, Harrisburg, PA 17110, USA \\ ${ }^{3}$ U.S. Forest Service, Northern Research Station, Parsons, WV 26287, USA
}

Correspondence should be addressed to W. Mark Ford; wmford@vt.edu

Received 1 March 2021; Revised 17 June 2021; Accepted 23 June 2021; Published 2 July 2021

Academic Editor: Nikolaos D. Hasanagas

Copyright (C) 2021 W. Mark Ford et al. This is an open access article distributed under the Creative Commons Attribution License, which permits unrestricted use, distribution, and reproduction in any medium, provided the original work is properly cited.

Before the arrival of white-nose syndrome in North America, the northern long-eared bat (Myotis septentrionalis) was a common cavity-roosting bat species in central Appalachian hardwood forests. Two successive prescribed burns on the Fernow Experimental Forest, West Virginia, in 2008 and 2009, were shown to positively affect maternity colony day-roost availability and condition in the near-term. However, whether immediate benefits were temporary and if burned forests actually experienced an accelerated loss of trees and snags possibly suitable for bats more than background loss in unburned forests became an important question following the species' threatened designation. In 2016, we revisited 81 of 113 northern long-eared bat maternity colony day-roosts initially discovered in 2007-2009 with the objective of ascertaining if these trees and snags were still standing and thus potentially "available" for bat use. Initial tree or snag stage condition class and original year of discovery were contributory factors determining availability by 2016, whereas exposure to prescribed fire and tree/snag species decay resistance were not. Because forest managers may consider using habitat enhancement to improve northern long-eared bat survival, reproduction, and juvenile recruitment and must also protect documented day-roosts during forestry operations, we conclude that initial positive benefits from prescribed burning did not come at the expense of subsequent day-roost loss greater than background rates in these forests at least for the duration we examined.

\section{Introduction}

Conservation of day-roosts is a central management tenet for many bat species. In much of eastern North America, particularly the heavily forested central and southern Appalachian Mountains, lack of forests and/or trees and snags is not a limiting factor per se as much as forest stand structure that provides optimal condition and spatial configuration of suitable roosts. For example, endangered Indiana bat (Myotis sodalis) summer maternity colonies often require recently fire or flood-disturbed older-age stands containing trees and snags with exfoliating bark and high solar exposure as their ideal roost conditions are ephemeral and transitory [1-4]. Unfortunately, with disrupted disturbance regimes, i.e., fire suppression, these suitable and often ephemeral conditions can be rare regionally in maturing deciduous forests [5]. Return of fire to the central Appalachian landscape through prescribing burning has been shown to improve foraging habitat conditions for bats generally by reducing forest "clutter" such as midstory growth $[6,7]$.

For day-roost conditions, burning improves, at least temporarily, conditions for Indiana bats and the threatened northern long-eared bats (Myotis septentrionalis) $[5,8]$. In the maternity season, female northern long-eared bat dayroosts are in cavities of live trees or standing snags across a wide variation in bole size and solar exposure [9]. Although some northern long-eared bat day-roosts are lost from collapse or combustion during a prescribed burn [8], repeated fires can accelerate the processes of both cavity 
formation and transitioning a healthy tree to a declining tree or snag [10] that is more suitable for a day-roost [11]. Similarly, in the near-term, northern long-eared bat maternity colonies select day-roosts in burned stands more than expected relative to unburned stands based on availability [8]. Ford et al. [12] observed a postfire reduction in trees and standing snags of species favored by northern long-eared bats. However, the proportion of trees and snags in advanced stages of decline or decay suitable for northern long-eared bat day-roosts increased postfire among highly used tree and snag species such as black locust (Robinia pseudoacacia) relative to unburned stands. Additionally, maternity colony social cohesion, as measured by the centrality of day-roosts used and numbers shared by conspecifics, was greater in burned stands than unburned stands [12].

The use of fire as a forest management tool in the central Appalachians typically is targeted towards other stewardship needs such as controlling shade-tolerant competition to foster oak (Quercus spp.) regeneration or to maintain early successional habitat types [13, 14]. Although evidence suggests that burning can provide benefits to bats in the region, questions remain about the longevity of bat dayroosts and the long-term effects following fire [15]. Disruption of northern long-eared bat maternity colony social networks can be caused by day-roost losses exceeding 30\% from one year to the next [16]. Because this species has been heavily impacted by white-nose syndrome, with population declines exceeding 90\% in the central Appalachians [17], forest managers now seek to enhance summer maternity day-roosting habitat for this species to promote successful reproduction and juvenile recruitment [18]. For northern long-eared bats, it is not known if prescribed fire provides only short-term day-roost benefits followed by an accelerated loss relative to background conditions. This could have conservation implications for the use of fire in forests where northern long-eared bats occur or the use of fire as a specific bat habitat management tool.

Accordingly, in 2016, we tracked fate (standing or fallen) of northern long-eared bat maternity colony day-roost trees and snags recorded from 2007 to 2009 at the Fernow Experimental Forest (FEF) in northcentral West Virginia $[8,11,12]$ in burned and unburned areas. We predicted that the probability of a day-roost tree or snag remaining in 2016 would be negatively related to initial tree or snag condition class when first discovered, positively related to tree or snag species wood specific gravity as a surrogate for wood decay resistance, negatively related to exposure to fire, and negatively related to time of original discovery.

\section{Methods}

2.1. Study Area. We examined data for northern long-eared bat day-roosts that were originally collected by $[5,8]$ from the FEF in northeastern West Virginia $\left(39^{\circ} 03^{\prime} 15^{\prime \prime} \mathrm{N}\right.$ $\left.79^{\circ} 41^{\prime} 15^{\prime \prime} \mathrm{W}\right)$. The FEF is a 1,900 ha experimental forest managed by the U.S. Forest Service, Northern Research Station, located in the unglaciated Allegheny Plateau portion of the central Appalachians. Topography is characterized by steep slopes and plateau-like ridgetops. Elevations range from $530 \mathrm{~m}$ to $1100 \mathrm{~m}$ [19]. Mean annual precipitation at FEF is $145.8 \mathrm{~cm}$ and mean annual temperature is $9.2^{\circ} \mathrm{C}$, with an average frost-free period of 145 days [20]. Forest stands on the FEF are a mosaic of second- and third-growth, mixedmesophytic, and northern hardwood types that have been managed by various even- and uneven-aged harvesting practices or have been left undisturbed following initial harvesting in the early 20 th century $[19,21]$. On parts of the FEF and much of the surrounding Monongahela National Forest, American chestnut (Castanea dentata) and oaks (Quercus spp.), such as northern red oak (Quercus rubra), historically dominated the forest overstory. However, chestnut blight (Cryphonectria parasitica) and subsequent lack of intense disturbance, including fire and harvesting, since the mid-20th century has allowed forest composition in unmanaged stands to shift toward shade-tolerant tree species, such as maples (Acer spp.) and American beech (Fagus grandifolia) [21]. Since 2002, prescribed fire has been used to promote oak regeneration in some FEF forest stands where the regeneration layer is currently dominated by sugar maple (Acer saccharum), red maple (Acer rubrum), yellowpoplar (Liriodendron tulipifera), black cherry (Prunus serotina), American beech, sweet birch (Betula lenta), and basswood (Tilia americana) [8, 22]. In early spring of 2007 and 2008, consecutive prescribed fires were conducted in a 121 ha compartment on the FEF that had been relatively free of management except for scattered light timber stand improvement entries in the previous decades. Treatment stands were burned using a strip head fire technique, ignited with handheld drip torches after fire-blackened perimeters were established [12].

2.2. Data Collection. During the summers of 2007-2009, we mist-netted and captured northern long-eared bats on the FEF in and around the burned compartment. Captured adult females were outfitted with radio-transmitters and tracked to their maternity colony day-roosts for the life of the transmitter or until the transmitter fell off. For complete details on mist-netting and tracking techniques, see $[8,11,12]$. Numerous metrics were recorded to describe and differentiate day-roost characteristics between the burned compartment and adjacent unburned stands such as diameter at breast height, crown class, condition class, bark retention, cavity presence, roost type (cavity or bark), and tree height of day-roost as well as surrounding basal area, and these data are presented elsewhere $[8,11,12]$. Because all located day-roosts from 2007 to 2009 were georeferenced and tagged, in the summer of 2016, U.S. Forest Service, Northern Research Station staff relocated a large portion of the day-roosts to establish necessary protective buffer zones pursuant to the requirements in the northern long-eared bat 4 (d) rule [23]. Located day-roosts were then recorded as live tree, standing snag, or fallen. No other measurements were collected nor were day-roosts checked for continued occupancy by northern long-eared bats or any other myotids, as the impacts of WNS and subsequent precipitous population declines $\sim 90 \%$ observed in Big Springs Cave, a sizable bat hibernaculum on the FEF, made that unlikely. It 
is possible that the other cavity-roosting bat species present, the big brown bat (Eptesicus fuscus), used these as dayroosts; however, none were noted roosting in earlier surveys [8], and their presence on FEF is relatively low [24].

2.3. Data Analysis. To assess the effect of being subjected to prescribed fire or unburned (FIRE), initial tree or snag condition class (STAGE: 1-7) [25], surrogate decay resistance rank from tree species specific gravity values collected at the FEF (RANK) [26], diameter at breast height (DBH), and year of initial discovery (YEAR: 2007-2009), we modeled the outcome of day-roosts remaining standing and presumably available versus fallen. Ideally, these data would be analyzed using a survival analysis approach [27]; however, without annual assessments from 2009 to 2016, this was not possible. Therefore, because we could only assess the final time step outcome, we used a generalized linear model with a binomial distribution and a logit link function (PROC GENMOD, SAS 10.2, Cary, NC). Surrogate decay resistance ranks were different among all species of trees and snags; therefore, this variable also served as a surrogate for species. Because determining if fire had an effect on day-roost availability was our primary question, all candidate models contained the FIRE variable. With FIRE, we modeled and ranked all combinations of the four variables (STAGE, RANK, DBH, and YEAR) using Akaike's information criteria (AIC) value corrected for small sample size [28].

\section{Results}

Of 113 northern long-eared bat day-roosts recorded from 2007 to 2009,81 were relocated in the 2016 search effort with 78 being used in our analyses. Three of these day-roosts had been cut from long-term silvicultural studies prior to the listing of the northern long-eared bat and were excluded. Of the 15 that were originally live trees, 12 remained alive and standing in 2016, 2 had become standing dead snags, and 1 tree had fallen. Of the 63 that were originally standing snags, 39 remained standing in 2016, whereas 24 had fallen. Trees and snags that remained available as day-roosts averaged $29.8 \pm 9.8 \mathrm{~cm}$ diameter at breast height at the time of original discovery, whereas those that had fallen averaged $26.6 \pm 6.8 \mathrm{~cm}$. Black locust, red maple, and sassafras (Sassafras albidum) comprised approximately $70 \%$ of the dayroosts relocated in 2016 with $40 \%, 36 \%$, and $38 \%$, respectively, becoming unavailable by 2016. Conversely, of the 10 northern red oaks, 3 chestnut oaks (Quercus prinus), one black oak (Quercus velutina), and one white oak (Quercus alba) monitored through 2016, only a single northern red oak, originally in decay stage 3 , and the one white oak, originally in decay stage 6, had fallen by 2016 .

The model retaining fire, initial decay stage, and year of initial day-roost discovery was the top supported model (Table 1). Day-roost species or size were not as important, as no model containing decay resistance rank or diameter at breast height was within $\Delta \mathrm{AIC}_{c}<2$. The only other variable combinations with support were fire and year of initial dayroost discovery or fire and initial decay stage (Table 1). From the top supported model, there was no difference in standing versus fallen outcomes attributable to exposure to prescribed burning (Table 2, Figure 1). Both original year of day-roost discovery and initial condition class affected day-roost availability by 2016 , though parameter estimate confidence intervals just crossed zero (Table 2). Day-roosts discovered initially in 2009 were less likely to remain standing in 2016 than those from 2007 to 2008 (Figure 1). Day-roosts in higher condition classes, i.e., live trees in decay stage 2 or snags with a higher degree of decay, upon initial discovery 2007-2009, were more likely to have fallen by 2016 (Figure 1).

\section{Discussion}

Ford et al. $[8,12]$ showed that relatively small-sized live trees and trees or snags in decay condition classes 2-6 [25] composed approximately $50 \%$ of day-roosts used on the FEF by northern long-eared bats. Black locust along with red maple, northern red oak, and black oak were the only species selected more than availability would suggest from the FEF's diverse tree species pool $[5,8,12]$. Irrespective of the introduction of fire, abundant numbers of small to mediumsized black locust and sassafras trees and snags with cavities suitable for northern long-eared bat day-roosts would be common in these FEF stands owing to the stand age and known patterns of stand development in the central Appalachians [29]. Although some day-roosts located initially in 2007 were snags that predated the two prescribed burns on the FEF, northern long-eared bats in 2008 and 2009 did use snags that were a direct result of tree mortality following fire $[8,12]$.

A preponderance of research, mostly from western North America, suggests that longevity of trees that become snags or current snags following fire can be one-third to onehalf as long as that in unburned stands [30]. These comparisons are relatively limited for deciduous forests where we worked or conifer, i.e., southern pine (Pinus spp.) or boreal systems in the East. Our data show no substantive difference in the probability of a burned tree or snag remaining available as a day-roost over time as compared to unburned trees at the FEF. In hardwood forests, surprisingly, snag persistence across most size classes of boles and tree species may only be about 10 years in the southern Piedmont [31] and 20-25 years in the northern Appalachians [32]. At the FEF, either the progression from tree to decaying snag to fallen coarse woody debris may occur quickly; masking fire effects on our resampling effort in 2016 had not allowed enough time to elapse for differentiation among rates of senescence. Despite a slightly higher probability of roost trees remaining available overall in unburned stands, the rates of change of availability between unburned and burned in our study were similar. For the most part, the loss of dayroosts following the two successive prescribed fires on the FEF probably did not cause loss more than background rates that were normally occurring as part of ongoing forest dynamic processes. Year of initial discovery was a factor contributing to long-term availability of day-roosts. Those initially found in 2009 were less likely to be available to 
TABLE 1: Competing generalized linear models and associated number of parameters $(K)$, Akaike's information criterion values $\left(\mathrm{AIC}_{c}\right)$, model rankings $\left(\triangle \mathrm{AIC}_{c}\right)$, and Akaike weights $\left(\omega_{i}\right)$ for predicting availability of northern long-eared bat (Myotis septentrionalis) day-roosts discovered in 2007-2009 and reexamined in 2016 on the Fernow Experimental Forest (FEF), West Virginia.

\begin{tabular}{|c|c|c|c|c|}
\hline Model $^{\mathrm{a}}$ & $K$ & $\mathrm{AIC}_{\mathrm{c}}$ & $\Delta \mathrm{AIC}_{\mathrm{c}}$ & $\omega_{i}$ \\
\hline FIRE + STAGE + YEAR & 4 & 97.81 & 0.00 & 0.25 \\
\hline FIRE + YEAR & 3 & 99.16 & 1.35 & 0.13 \\
\hline FIRE + STAGE & 3 & 99.17 & 1.36 & 0.13 \\
\hline $\mathrm{FIRE}+\mathrm{DBH}+\mathrm{RANK}+\mathrm{YEAR}$ & 5 & 99.96 & 2.15 & 0.09 \\
\hline FIRE & 2 & 100.03 & 2.22 & 0.08 \\
\hline FIRE + RANK + STAGE + YEAR & 5 & 100.07 & 2.26 & 0.08 \\
\hline FIRE + DBH + STAGE + YEAR & 5 & 100.64 & 2.83 & 0.06 \\
\hline FIRE + DBH + STAGE & 4 & 101.22 & 3.41 & 0.05 \\
\hline $\mathrm{FIRE}+\mathrm{DBH}+\mathrm{YEAR}$ & 4 & 101.27 & 3.46 & 0.04 \\
\hline FIRE + RANK + STAGE & 4 & 101.35 & 3.54 & 0.04 \\
\hline FIRE + RANK + YEAR & 4 & 101.39 & 3.58 & 0.04 \\
\hline $\mathrm{FIRE}+\mathrm{DBH}$ & 3 & 101.98 & 4.17 & 0.03 \\
\hline FIRE + RANK & 3 & 102.23 & 4.42 & 0.03 \\
\hline GLOBAL $($ FIRE + DBH + RANK + STAGE + YEAR $)$ & 6 & 102.28 & 4.47 & 0.03 \\
\hline $\mathrm{FIRE}+\mathrm{DBH}+\mathrm{RANK}+\mathrm{STAGE}$ & 5 & 103.52 & 5.71 & 0.01 \\
\hline $\mathrm{FIRE}+\mathrm{DBH}+\mathrm{RANK}$ & 4 & 104.09 & 6.28 & 0.01 \\
\hline
\end{tabular}

${ }^{a}$ FIRE, prescribed fire vs. unburned; STAGE, initial day-roost decay class condition; YEAR, year of day-roost discovery; RANK, surrogate decay resistance rank from tree species specific gravity values collected at the FEF; DBH, diameter at breast height of day-roost at initial discovery.

TABLE 2: Parameter estimates of the best approximating model for predicting availability of northern long-eared bat (Myotis septentrionalis) day-roosts discovered in 2007-2009 and reexamined in 2016 on the Fernow Experimental Forest, West Virginia.

\begin{tabular}{lcccccr}
\hline Variable $^{\mathrm{a}}$ & d.f. & Parameter estimate & Standard error & \multicolumn{2}{c}{ Wald 95\% confidence } & Wald $\chi^{2}$ \\
\hline Intercept & 1 & 1765.80 & 959.22 & -114.24 & 3645.84 & 3.39 \\
Fire & 1 & 0.48 & 0.54 & -0.58 & 1.54 & 0.79 \\
Stage & 1 & -0.32 & 0.18 & -0.67 & 0.02 & 3.33 \\
Year & 1 & -0.88 & 0.80 & -1.81 & 0.06 & 3.38 \\
\hline
\end{tabular}

${ }^{a}$ FIRE, prescribed fire vs. unburned; STAGE, initial day-roost decay class condition; YEAR, year of day-roost discovery; RANK, surrogate decay resistance rank from tree species specific gravity values collected at the FEF; DBH, diameter at breast height of day-roost at initial discovery.

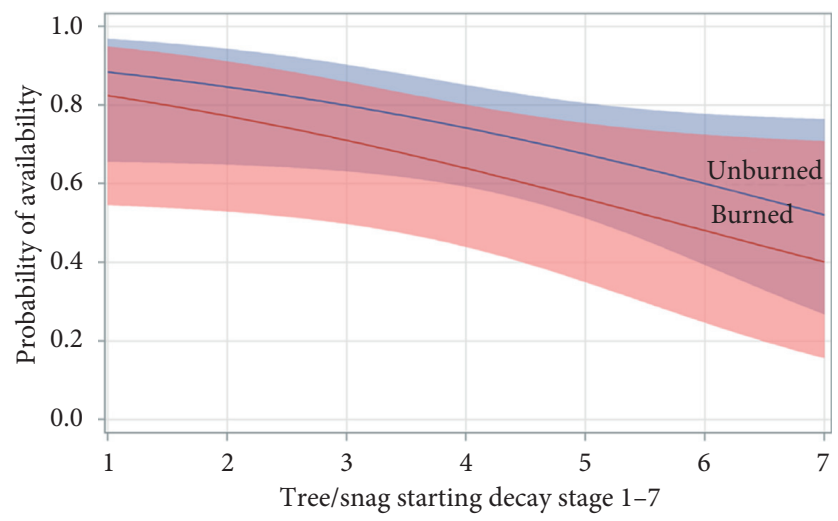

FIGURE 1: Probability of northern long-eared bat (Myotis septentrionalis) day-roosts being available (standing) in 2016 relative to exposure to two prescribed fires and initial day-roost decay stage on the Fernow Experimental Forest, West Virginia, 2007-2009. Shading represents the 95\% credible estimate around the prediction.

northern long-eared bats by 2016. However, we attribute this paradox to the relatively small number (4) of new day-roosts, only in burned stands, added in 2009. It is possible, of course, that these day-roosts were also used in 2007 and 2008 without being documented, as northern long-eared bat maternity colonies often will occupy the same relatively small general location for successive years in temperate deciduous forests so long as day-roosts are suitable [9]. 
What remains unknown from our assessment of dayroost availability on the FEF is the annual to long-term trend in recruitment and loss in live trees and snags with cavities suitable for northern long-eared bats. Cavity tree and snag abundance can be highly variable in the central and southern Appalachians depending on forest type [33], though often, there is no relationship between these and forest stand age [34]. Archived data from an unmanaged watershed on the FEF showed there was an annual recruitment of 0.4 snags/ ha/year $>12.7 \mathrm{~cm}$. In mid-1960s, there was an average of 15.5 snags/ha increasing to $38.1 /$ ha by 2019 , densities greater than per area needs of northern long-eared bat maternity colonies [35]. Subtle changes in snag species are apparent over these $50+$ years with early successional black locust and sassafras comprising a large proportion of snags initially and then oak snags increasing in three decades later, a group highly selected as day-roosts for the northern long-eared bat in the southern Appalachians [36].

\section{Conclusions}

Some forest dwelling bat species require a shifting mosaic across the landscape of some ephemeral trees or stand conditions [5, 37]. At the landscape scale in central Appalachian oak-pine forests, prescribed fire has been shown capable of providing that stand condition heterogeneity [38]. However, the day-roost ecology of the northern long-eared bat operates more at the forest stand level and with a high cosmopolitan use of a wide range of trees or snags sizes across multiple species including very small $(<10 \mathrm{~cm} d b h)$ boles in midaged to old-growth deciduous forests $[9,39]$ amenable to the changes from stand level burning [10]. Assuming potential day-roosts recruitment approximates or exceeds annual losses over successive years and/or any given natural or anthropogenic disturbance does not remove a relatively large number of day-roosts in a given year [16], forest conditions on the FEF probably provide sufficient roost conditions from year to year in most stands. The studies $[8,11,12]$ clearly demonstrated benefits to northern long-eared bat maternity colonies as a result of two prescribed burns. Whether this would be true with multiple fires and/or long-term management by frequent fires in this forest or other forest types in the species' distribution is unknown and merits further research. Also, owing to the decline in bat numbers due to white-nose syndrome, we have no way of knowing if continued use or potential abandonment by bats due to some interactions of being within a burned stand across the decay class continuum would have occurred. Nonetheless, our study adds clarity to fire and roost availability by showing that an accelerated loss of dayroosts in burned stands versus unburned stands did not occur over the time examined. This is useful for both forest managers and those tasked with conserving the northern long-eared bat from a regulatory standpoint.

\section{Data Availability}

The datasets used and/or analyzed during the current study are available from the corresponding author upon request.

\section{Disclosure}

Any use of trade, firm, or product names is for descriptive purposes only and does not imply endorsement by the U.S. Government.

\section{Conflicts of Interest}

The authors declare that they have no conflicts of interest.

\section{Authors' Contributions}

WMF and JBJ conceived the study. WMF provided study oversight, performed the analyses, and prepared the manuscript. JBJ and MTV collected field data. WMF, JBJ, and MTV interpreted the data and edited and prepared the manuscript for submission.

\section{Acknowledgments}

The authors thank D. Lowther, R. Hovatter, M. Karp, J. Rodrigue, T. Schuler, and numerous FEF summer interns for field assistance throughout this effort. Financial support for this project was provided by U.S. Forest Service, Northern Research Station.

\section{References}

[1] M. A. Menzel, J. M. Menzel, T. C. Carter, W. M Ford, and J. W. Edwards, "Review of the forest habitat relationships of the Indiana bat (Myotis sodalis)," USDA Forest Service, Northeastern Research Station General Technical Report NE284, Newtown Square, PA, USA, 2001.

[2] E. R. Britzke, M. J. Harvey, and S. C. Loeb, "Indiana bat, Myotis sodalis, maternity roosts in the southern United States," Southeastern Naturalist, vol. 2, no. 2, pp. 235-242, 2003.

[3] T. C. Carter, W. M. Ford, and M. A. Menzel, "Fire and bats in the southeast and mid-Atlantic: more questions than answers?," in The Role of Fire in Nongame Wildlife: Traditional Uses and New Directions, W. M. Ford, K. R. Russell, and C. E. Moorman, Eds., pp. 139-143, USDA Forest Service Northeastern Research Station General Technical Report NE288, Newtown Square, PA, USA, 2002.

[4] J. M. O'Keefe and S. C. Loeb, "Indiana bats roost in ephemeral, fire-dependent pine snags in the southern Appalachian Mountains, USA," Forest Ecology and Management, vol. 391, pp. 264-274, 2017.

[5] J. B. Johnson, W. M. Ford, J. L. Rodrigue, J. W. Edwards, and C. M. Johnson, "Roost selection by male Indiana Myotis following forest fires in central Appalachian hardwoods forests," Journal of Fish and Wildlife Management, vol. 1, no. 2, pp. 111-121, 2010.

[6] L. V. Austin, A. Silvis, W. Mark Ford, and K. E. Powers, "Effects of historic wildfire and prescribed fire on site occupancy of bats in Shenandoah National Park, Virginia, USA," Journal of Forestry Research, vol. 31, no. 4, pp. 1255-1270, 2019.

[7] L. V. Austin, A. Silvis, M. S. Muthersbaugh, K. E. Powers, and W. Mark Ford, "Bat activity following repeated prescribed fire in the central Appalachians, USA," Fire Ecology, vol. 14, no. 2, p. 10, 2018. 
[8] J. B. Johnson, J. W. Edwards, W. M. Ford, and J. E. Gates, "Roost tree selection by northern myotis (Myotis septentrionalis) maternity colonies following prescribed fire in a Central Appalachian Mountains hardwood forest," Forest Ecology and Management, vol. 258, no. 3, pp. 233-242, 2009.

[9] A. Silvis, R. W. Perry, and W. M. Ford, "Relationships of three species of White-nose Syndrome-impacted bats to forest condition and management," Technical Report. SRS-214, USDA Forest Service Southern Research Station General, Ashville, NC, USA, 2016.

[10] S. Stanis, J. Wiedenbeck, and M. R. Saunders, "Effect of prescribed fire on timber volume and grade in the Hoosier National Forest," Forest Science, vol. 65, no. 6, pp. 714-724, 2019.

[11] J. B. Johnson, W. Mark Ford, and J. W. Edwards, "Roost networks of northern myotis (Myotis septentrionalis) in a managed landscape," Forest Ecology and Management, vol. 266, pp. 223-231, 2012.

[12] W. M. Ford, A. Silvis, J. B. Johnson, J. W. Edwards, and M. Karp, "Northern long-eared bat day-roosting and prescribed fire in the Central Appalachians, USA," Fire Ecology, vol. 12, no. 2, pp. 13-27, 2016.

[13] P. Brose, T. Schuler, D. Van Lear, and J. Berst, "Bringing fire back. the changing regimes of the Appalachian oak forest," Journal of Forestry, vol. 99, pp. 30-35, 2001.

[14] C. A. Harper, W. M. Ford, M. A. Lashley, C. E. Moorman, and M. C. Stambaugh, "Fire effects on wildlife in the central hardwoods and appalachian regions, USA," Fire Ecology, vol. 12, no. 2, pp. 127-159, 2016.

[15] M. B. Dickenson, M. J. Lacki, and D. R. Cox, "Fire and the endangered Indiana bat," in Proceedings of the 3rd Fire in Eastern Oak Forest Conference, T. F. Hutchison, Ed., pp. 5175, USDA Forest Service Northern Research Station General Technical Report NRS-P-46, Newtown Square, PA, USA, 2009.

[16] A. Silvis, W. M. Ford, and E. R. Britzke, "Effects of hierarchical roost removal on northern long-eared bat (Myotis septentrionalis) maternity colonies," PLoS One, vol. 10, no. 1, Article ID e0116356, 2015.

[17] R. J. Reynolds, K. E. Powers, W. Orndorff, W. M. Ford, and C. S. Hobson, "Changes in rates of capture and demographics of myotisseptentrionalis (Northern Long-eared Bat) in Western Virginia before and after onset of white-nose syndrome," Northeastern Naturalist, vol. 23, no. 2, pp. 195-204, 2016.

[18] J. L. Cruz, R. L. Ward, and E. S. Schroder, "Landscape characteristics related to use of artificial roosts by northern long-eared bats in north-central West Virginia," Northeastern Naturalist, vol. 25, no. 3, pp. 487-501, 2018.

[19] W. M. Ford, M. A. Menzel, J. L. Rodrigue, J. M. Menzel, and J. B. Johnson, "Relating bat species presence to simple habitat measures in a central Appalachian forest," Biological Conservation, vol. 126, no. 4, pp. 528-539, 2005.

[20] D. M. Madarish, J. L. Rodrigue, and M. B. Adams, "Vascular flora and macroscopic fauna on the Fernow experimental forest," Technical Report NE-291, USDA Forest Service, Northeastern Research Station, Newtown Square, PA, USA, 2002.

[21] T. M. Schuler, "Fifty years of partial harvesting in a mixed mesophytic forest: composition and productivity," Canadian Journal of Forest Research, vol. 34, no. 5, pp. 985-997, 2004.

[22] W. M. Ford, S. F. Owen, J. W. Edwards, and J. L. Rodrigue, "Robinia pseudoacacia (black locust) as day-roosts of male Myotis septentrionalis (northern bats) on the Fernow experimental forest, West Virginia," Northeastern Naturalist, vol. 13, no. 1, pp. 15-24, 2006.

[23] USFWS. 2016, Endangered and Threatened Wildlife and Plants; 4(d) Rule for the Northern Long-Eared Bat, Federal Register, Washington, DC, USA, 2016.

[24] S. P. Bombaci, M. J. Germain, W. M. Ford et al., "Context dependency of disease-mediated competitive release in bat assemblages following white-nose syndrome," Ecosphere, vol. 19, 2021 (In press).

[25] S. P. Cline, A. B. Berg, and H. M. Wight, "Snag characteristics and dynamics in Douglas-fir forests, western Oregon," The Journal of Wildlife Management, vol. 44, no. 4, pp. 773-786, 1980.

[26] M. B. Adams and D. R. Owen, Specific Gravity of Coarse Woody Debris for Some Central Appalachians Hardwood Forest Species, USDA Forest Service Research Paper NE-716, Newtown Square, PA, USA, 2001.

[27] A. B. Edworthy, K. L. Wiebe, and K. Martin, "Survival analysis of a critical resource for cavity-nesting communities: patterns of tree cavity longevity," Ecological Applications, vol. 22, no. 6, pp. 1733-1742, 2012.

[28] K. P. Burnham and D. R. Anderson, Model Selection and Multi-Model Inference: A Practical Information-Theoretic Approach, Springer, New York, NY, USA, 2002.

[29] W. C. McComb and R. N. Muller, "Snag densities in oldgrowth and second-growth Appalachian forests," The Journal of Wildlife Management, vol. 47, no. 2, pp. 376-382, 1983.

[30] V. A. Angers, S. Gauthier, P. Drapeau, K. Jayen, and Y. Bergeron, "Tree mortality and snag dynamics in North American boreal tree species after a wildfire: a long-term study," International Journal of Wildland Fire, vol. 20, no. 6, pp. 751-763, 2011.

[31] C. E. Moorman, K. R. Russell, G. R. Sabin, and D. C. Guynn, "Snag dynamics and cavity occurrence in the South Carolina Piedmont," Forest Ecology and Management, vol. 118, no. 1-3, pp. 37-48, 1999.

[32] M. Yamasaki and W. B. Leak, "Snag longevity in managed northern hardwoods," Northern Journal of Applied Forestry, vol. 23, no. 3, pp. 215-217, 2006.

[33] A. Evans, Ecology of Dead Wood in the Southeast, The Forest Guild, Santa Fe, NM, USA, 2012.

[34] A. T. Graves, M. A. Fajvan, and G. W. Miller, "The effects of thinning intensity on snag and cavity tree abundance in an Appalachian hardwood stand," Canadian Journal of Forest Research, vol. 30, no. 8, pp. 1214-1220, 2000.

[35] A. Silvis, W. M. Ford, E. R. Britzke, and J. B. Johnson, "Association, roost use and simulated disruption of Myotis septentrionalis maternity colonies," Behavioural Processes, vol. 103, pp. 283-290, 2014.

[36] J. M. O'Keefe, Roosting and foraging ecology of forest bats in the southern Appalachian Mountains, Ph.D. Dissertation, Clemson University, Clemson, SC, USA, 2009.

[37] K. J. Bondo, C. K. R. Willis, J. D. Metheny et al., "Bats relocate maternity colony after the natural loss of roost trees," The Journal of Wildlife Management, vol. 83, no. 8, pp. 1753-1761, 2019.

[38] J. Lorber, M. Thomas-Van Gundy, and S. Croy, Characterizing Effects of Prescribed Fire on Forest Canopy Cover in the George Washington and Jefferson National Forests, USDA Forest Service Northern Research Station Research Paper. NRS-RP31, Newtown Square, PA, USA, 2018.

[39] M. S. Muthersbaugh, "Seasonal activity patterns of bats in the central appalachians," M. S. thesis, Virginia Polytechnic Institute and State University, Blacksburg, VA, USA, 2018. 